\title{
Pedicle frozen autograft for limb sparing surgery in a dog with femoral osteosarcoma
}

\author{
Autoenxerto pedicular congelado para preservação do membro \\ em um cão com osteossarcoma femoral
}

\author{
Aline Silva Gouvêa ${ }^{I}$ Juliana Lichtler ${ }^{I}$ Simone Scherer $^{I}$ Verônica Santos Mombach $^{\mathrm{I}}$ \\ Kauê Danilo Helene Lemos dos Reis ${ }^{I}$ Paula Cristina Sieczkowski Gonzalez ${ }^{I}$ \\ Luciana Sonne ${ }^{I I}$ Marcelo Meller Alievi ${ }^{{ }^{*}}$
} \begin{abstract}
tumor diagnosed in dogs and represents approximately $85 \%$ of canine skeletal tumors. The most commonly employed therapy is amputation of the limb followed by chemotherapy. However, preservation of the afflicted limb has been successful for patients with concomitant neurological or orthopedic conditions, which are contraindications to the complete amputation, or with owners reluctant to the possibility of amputation. For these reasons, the purpose of this study was to describe the technical procedures that allowed limb salvage through the use of pedicle frozen grafts in a dog with femoral OSA. Surgical procedures consisted of a femoral diaphyseal osteotomy with tearing of the soft tissues; thus, creating a bone pedicle that was frozen in liquid nitrogen according to the protocol outlined by TSUCHIYA et al. (2005). Limb function remained satisfactory for six months.
\end{abstract}

- NOTE em nitrogênio líquido, seguindo o protocolo realizado por TSUCHIYA et al. (2005). O cão permaneceu com a função satisfatória do membro por um periodo de seis meses.

Palavras-chave: tumor ósseo, canino, crioterapia.

Key words: bone tumor, canine, cryotherapy.

RESUMO

Dentre os tumores ósseos que acometem os cães, o osteossarcoma (OSA) é o mais frequentemente diagnosticado e representa $85 \%$ das neoplasias de origem esquelética. A terapêutica comumente indicada é a amputação do membro, seguida de quimioterapia. No entanto, a preservação do membro afetado tem sido realizada em pacientes com afecções neurológicas ou ortopédicas concomitantes, que contraindicam a amputação radical ou em caso de tutores relutantes em aceitar a amputação. Em razão disso, o objetivo do presente trabalho é descrever a técnica de preservação de membro através de pedículo congelado em nitrogênio líquido em um cão com osteossarcoma de fêmur. A técnica cirúrgica empregada consistiu na osteotomia diafisária do fêmur, com divulsão dos tecidos moles, criando assim o pedículo ósseo que foi congelado
Osteosarcoma (OSA) is the most frequent type of bone tumor (85\%) and represents $3 \%$ to $4 \%$ of all tumors in dogs (BURACCO et al., 2002, JOHNSON \& HULSE, 2005). The diagnosis is based on the medical history, physical examination, radiological findings, bone scintigraphy, and computed tomography results. Confirmation of the diagnosis is achieved with tumor biopsy followed by histopathological examination (LIPTAK et al., 2004).

The purpose of OSA treatment is to allow local control of the disease and to prevent metastasis. Amputation and limb preservation are two possible treatment options for the primary tumor; whereas, chemotherapy is required to minimize the risk of developing metastases. Limb preservation surgery, referred to as "limb-sparing," was developed for special cases in which the patient has other relevant concomitant diseases, such as a neurological or orthopedic disease, or when the owners do not allow amputation (BURACCO et al., 2002; LIPTAK, 2004).

Limb sparing surgery provides pain-free, functional use for the patient without adversely affecting survival. Among the several techniques

\footnotetext{
IHospital de Clinicas Veterinárias (HCV), Faculdade de Veterinária (FAVET), Universidade Federal do Rio Grande do Sul (UFRGS), Av. Bento Gonçalves, 9090, Bairro Agronomia, 91540-000, Porto Alegre, RS, Brasil. E-mail: marcelo.alievi@ufrgs.br. "Corresponding author.

"Setor de Patologia Veterinária, Faculdade de Veterinária (FAVET), Universidade Federal do Rio Grande do Sul (UFRGS), Porto Alegre, RS, Brasil. 
that can be employed for limb sparing, substitution of the neoplastic region by allogeneic or autologous grafts is the most commonly used technique (EHRHART et al., 2013).

Reconstruction using the autologous neoplastic bone requires devitalization that can be achieved by autoclaving, pasteurizing, or irradiation of the bone. However, these treatments demand the use of special equipment and involve heating procedures that can weaken the bone and decrease osteoinduction. For these reasons, TSUCHIYA et al. (2005) have developed a devitalization procedure in humans that involves freezing the bone in liquid nitrogen. There are several advantages associated with this method including its simplicity and low cost as well as maintenance of the osteoinduction and bone osteoconduction properties, perfect adaptation between the bone interfaces, biomechanical strength, lack of disease transmission, lack of immunological graft rejection, no need for a bone donor bank, and no special equipment (TSUCHIYA et al., 2010).

The case report aimed to describe the techniques employed to preserve a limb with OSA through freezing the pedicle in liquid nitrogen and using chemotherapy. An eight-year-old, 33kg, male, Great Dane mix was attended with a history of claudication of the right pelvic limb over the past month. Physical examination showed a slight increase in volume at the distal diaphyseal region of the femur as well as muscle atrophy. OSA was diagnosed through X-ray and a biopsy (osteosblastic osteosarcoma).

The informed consent form was read and signed by the owner, and the patient was directed to limb preservation surgery. The animal was anesthetized and the limb was prepared for aseptic surgery. Antimicrobial prophylactics were administered intravenously $\left(22 \mathrm{mg} \mathrm{kg}^{-1}\right.$ of ampicillin sodium) 30 minutes before the surgery and every 2 hours during the perioperative period.

With the patient in the left lateral recumbency, the femur was approached through the craniolateral portal with an incision in the fascia lata and caudal retraction of the biceps femoris muscle as well as cranial retraction of the vastus lateralis. Exposure of the femur allowed osteotomy at the proximal diaphyseal region (at a distance of $2 \mathrm{~cm}$ from the tumor border) with the use of a pneumatic oscillating saw. Following osteotomy, and after isolating the tumor region from the soft tissues, the bone marrow was scraped and the patient's limb was rotated towards the stainless steel bowl containing liquid nitrogen to create a pedicle frozen autograft. The tumor was completely immersed in liquid nitrogen at $-196^{\circ} \mathrm{C}$. The soft tissues were protected with gauze and surgical pads. The devitalization protocol was performed according to procedures outlined by TSUCHIYA et al. (2005), with the pedicle remaining in liquid nitrogen for 20 minutes, followed by incubation at room temperature for 15 minutes and then in distilled water for 10 minutes. After the devitalization procedure, all surgical instruments and pads were replaced and bone cement was used to refill the devitalized bone marrow cavity; osteosynthesis was then performed with the use of a dynamic compression plate and nine cortical screws (Figure 1). In the end of the surgery, the soft tissues were sutured using routine procedures.

After the surgery, the patient was given the following analgesics: ketamine $\left(1 \mathrm{mg} \mathrm{kg}^{-1} \mathrm{IM}\right)$ every 12 hours for 2 days; meloxicam $(0.1 \mathrm{mg}$ $\mathrm{kg}^{-1} \mathrm{IM}$ ) every 24 hours for 3 days, tramadol (5 $\mathrm{mg} \mathrm{kg}^{-1} \mathrm{VO}$ ) every 8 hours, for 10 days; sodium dipyrone $\left(25 \mathrm{mg} \mathrm{kg}^{-1} \mathrm{VO}\right)$ every 8 hours, for 5 days, and the antibiotic amoxicillin/clavulanate potassium (20 $\mathrm{mg} \mathrm{kg}^{-1} \mathrm{VO}$ ) every 12 hours, for 15 days. Chemotherapy protocol was carboplatin $\left(300 \mathrm{mg} \mathrm{m}^{2}\right.$ ) each 3 weeks, during 4 sessions.

A hyperemic circle of $3 \mathrm{~cm}$ that did not include the surgical wound was observed in the proximal region of the limb after the surgery and progressed to a superficial skin lesion and eventually gave rise to scar tissue. Radiographic control of the operated limb and of the thorax was performed monthly. The dog maintained a functional limb for approximately 180 days. After this period, there was a progressive reduction of limb usage and associated with restricted amplitude of the knee joint movement. Together with the owner, a decision was made to perform the amputation of the limb; the histopathological analysis showed local tumor recurrence. The patient survived for 240 days and died due to pulmonary metastasis.

According to LIPTAK et al. (2004) and FERRIGNO (2011), the initial reluctance of the owner to amputation was the main reason for choosing limb sparing technique as showed in this report. The owner was informed about the possibility of complications because at the liquid nitrogen in limb sparing technique application, especially because this technique is still in development and not yet routinely applied in dogs.

Limb sparing techniques are limited by the surgical procedures available (osteogenesis by distraction or vascularized autograft), lack of access to specialized equipment (irradiation and autograft), and lack of availability of a bone bank 


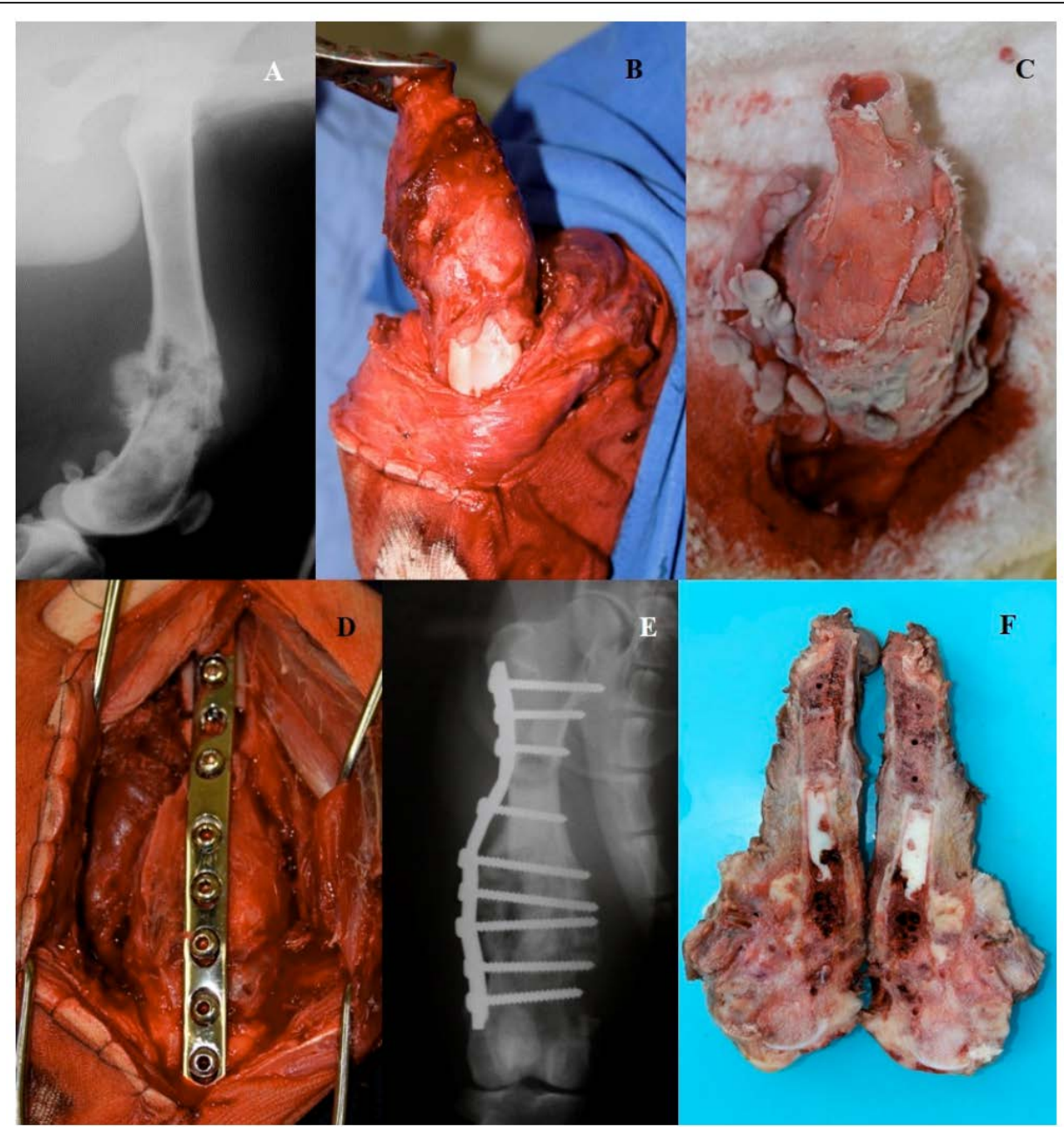

Figure 1 - Limb sparing of the distal femur in dog. Radiographic compatible with osteosarcoma of the distal femur (A). Following osteotomy and after isolating the tumor region from the soft tissues (B). After, to create a pedicle frozen autograft, the tumor was completely immersed in liquid nitrogen at $-196^{\circ} \mathrm{C}(\mathrm{C})$. Osteosynthesis was then performed with the use of a dynamic compression plate and nine cortical screws (D). Radiographic control of the operated limb (E) After amputation of the limb (F).

(BURACCO et al., 2002; LIPTAK et al., 2006). These problems and limitations suggested the use of cryosurgery with use of liquid nitrogen, as this procedure does not require specific equipment, is inexpensive, and has been successfully performed in humans (TSUCHIYA et al., 2005; TSUCHIYA et al., 2010; TORIGOE et al., 2012).

Limb sparing in cases of OSA located in the distal femur region has been discouraged because of elevated complication rates, low tolerance towards arthrodesis, and limited availability of knee prostheses (DERNELL et al., 2001). However, in this case, the pedicle technique with one point of osteotomy was viable and allowed the patient to have satisfactory functional use of the limb for six months without compromising the movement of the knee joint.

Compared to the excision technique (complete tumor removal), the pedicle technique has several advantages including maintenance of articulation continuity (in some cases) and fewer osteotomy incisions. Nevertheless, the technique also has some disadvantages such as broad disruption of the soft tissues and difficulty to rotate the limb towards the freezing container (TSUCHIYA et al., 2010; TORIGOE et al., 2012). Both problems were observed in this case. 
Incorporation of the graft in the receiving cavity is critical; however, in most cases the autograft does not consolidate completely and acts as a simple spacer. Furthermore, consolidation can last up to two years, which is usually longer than the life expectancy of most of the patients (LIPTAK et al., 2004). One considerable advantage of the pedicle technique is that osteotomy and desarticulation are only performed at one point, maintaining the continuity of the column and; therefore, minimizing possible complications due to disrupted interfaces, and, consequently, minimizing graft failure and reabsorption. During the follow-up period (6 months), the interface autograft-receptor bed did not showed signs of consolidation, but this did not lead to clinical complications. According to LIPTAK et al. (2004) the clinical impact of the non-existing junction is minimal when the interface between the host bone and the graft is strongly stabilized and protected with a dynamic compression plate.

Tumor recurrence is one possible complication of limb preservation. A study by FERRIGNO (2011) reported that recurrence rates were lower in other countries when compared to Brazil. Brazilian osteosarcomas cases are considered different because many owners hesitate to search for veterinary care, making a late diagnosis of osteosarcoma when it is already large and more invasive. In the present case, the tumor was not in an early stage, which may have influenced the disease progression and outcome.

Despite tumor recurrence, we concluded that the proposed pedicle technique can be considered viable and feasible in patients with OSA located in the distal femur; however, more studies are required before this technique can be used in routine veterinary procedures.

\section{ACKNOWLEDGEMENTS}

The authors would like to thank by the financial support from Conselho Nacional de Desenvolvimento Científico e Tecnológico (CNPq) (Edital Universal 2013), number 480398/2013-5.

\section{BIOETHICS AND BIOSSECURITY COMMITTEE APPROVAL}

The project was approved by Institutional Animal Care of Universidade Federal do Rio Grande do Sul (UFRGS) under the protocol number 24463.

\section{REFERENCES}

BURACCO, P. et al. Pasteurized tumoral autograft as a novel procedure for limb sparing in the dog: a clinical report. Veterinary Surgery, n.31, p.525-532, 2002. Available from: $<$ http://onlinelibrary.wiley.com/doi/10.1053/jvet.2002.34674/ abstract $>$. Accessed: Jul. 22, 2016. doi: 10.1053/ jvet.2002.34674.

DERNELL, W.S. et al. Tumor of skeletal system. In: WITHROW, S.J; MACEWENS, E.G. Small animal clinical oncology. Philadelphia: Saunders Company, 2001. p.378-417.

EHRHART, N.P. et al. Tumors of the skeletal system. In: WITHROW, S.J; MACEWENS, E.G. Small animal clinical oncology. Philadelphia: Saunders Company, 2013. p.463-495.

FERRIGNO, C.R.A. Tratamento de neoplasias ósseas apendiculares com reimplantação de enxerto ósseo autólogo autoclavado associado ao plasma rico em plaquetas: estudo crítico na cirurgia de preservação de membro em cães. 2011. $128 f$. Tese de Livre Docência, Universidade de São Paulo.

JOHNSON, A.L.; HULSE, D.A. Neoplasias ósseas. In: FOSSUM, T.W. Cirurgia de Pequenos Animais. 2.ed. São Paulo: Roca, 2005. p.1165-1176.

LIPTAK, J.M. et al. Canine appendicular osteosarcoma: curative-intent treatment. Compendium on Continuing Education for the Practicing Veterinarian, v.26, n.3, p.186197, 2004. Available from: <http://www.vetfolio.com/oncology/ canine-appendicular-osteosarcoma-curative-intent-treatment $>$. Accessed: Jul. 22, 2016.

LIPTAK, J.M. et al. Cortical allograft and endoprosthesis for limb-sparing surgery in dogs with distal radial osteosarcoma: a prospective clinical comparison of two different limb-sparing techniques. Veterinary Surgery, v.35, n.6, p.518-533, 2006. Available from: <http://onlinelibrary.wiley.com/doi/10.1111/ j.1532-950X.2006.00185.x/abstract>. Accessed: Jul. 22, 2016. doi: 10.1111/j.1532-950X.2006.00185.X.

TORIGOE, T. et al. Pedicle freezing with liquid nitrogen for malignant bone tumour in the radius: a new technique of osteotomy of the ulna. Journal of Orthopaedic Surgery, v.20, n.1, p.98-102, 2012. Available from: <http://www.josonline. org/index.php/JOS/article/view/153>. Accessed: Jul. 22, 2016.

TSUCHIYA, H. et al. Reconstruction using an autograft containing tumour treated by liquid nitrogen. Bone and Joint Surgery, v.87B, p.218-225, 2005. Available from: <http://www.bjj.boneandjoint. org.uk/content/87-B/2/218>. Accessed: Jul. 22, 2016. doi: 10.1302/0301-620X.87B2.15325.

TSUCHIYA, H. et al. Pedicle frozen autograft reconstruction in malignant bone tumors. Journal of Orthopaedic Science, v.15, p.340-349, 2010. Available from: <http://www.sciencedirect.com/ science/article/pii/S0949265815309593>. Accessed: Jul. 22, 2016. doi: 10.1007/s00776-010-1458-0. 